\title{
A STUDY OF LITERATURE: CRYPTOCURRENCY OF SYARIAH PERSPECTIVE
}

\author{
*Fuadi ${ }^{1}$, Afrizal ${ }^{2}$, M. Shabri Abd. Majid ${ }^{3}$, Marliyah ${ }^{4}$, Rita Handayani ${ }^{5}$ \\ ${ }^{1}$ Faculty of Economics and Business Universitas Malikussaleh \\ ${ }^{2}$ Faculty of Economics and Business, Universitas Syiah Kuala \\ ${ }^{3,4,5}$ Faculty of Economics and Islamic Business UIN Sumatera Utara Medan \\ Correspondence: fuadi.msm@unimal.ac.id
}

\begin{abstract}
Cryptocurrency is a digital or virtual currency, which does not have a physical form like fiat money. This crypto currency can only be used through devices such as PCs, laptops, smartphones and other devices that are connected to the internet. There are several advantages in a crypto system that uses blockchain system, such as transaction security, convenience, speed and can be used across countries and continents, however cryptocurrency which is currently circulating also still have weaknesses, including there is no supervisory authority, even many countries have disagreements over the legality of this cryptocurrency. The debate about the pros and cons regarding to the use of cryptocurrency becomes dynamics among the experts including the scholars who have study from Islamic point of view. This research aims to examine the dynamics of using cryptocurrency from ushul figh point of view, where the methods which used in this research are al-qur'an, al-Hadith, Qiyas and Sad-Adzariyah. Basically the use of cryptocurrency is allowed to meet cetain conditions that is by removing batil elements as in Quran surah An-Nisa verse 29, those batil elements are gharar and mayshir. Moreover, cryptocurrency must also have clear legality in a country for security in their use.
\end{abstract}

Keywords: Cryptocurrency, Usul Fiqh, Digital, Virtual, Money

\section{INTRODUCTION}

The digital world is currently developing very fast, the global community feels its development is so massive. The phenomenon of the development of information technology brings benefits and certainly affects the dynamics of social life in society, such as in getting information and interacting, economic activities are also becoming more dynamic, such as online transactions, buying and selling activities and leasing products or services through online. The transaction tools used also experienced dynamic changes, the use of the medium of exchange began with a barter system, where people exchanged their commodity goods with each other, but the weakness in this barter system was the difficulty in determining the price of goods. The shift in the medium of exchange in transactions is the use of precious metals such as gold and silver, the two precious metals are also used as religious measuring tools in Islam such as the nishab of zakat and kafarat. In general, the requirements for money to be fulfilled as a tool in transactions to be accepted are that it has a function as a medium of change, as a unit of account and has a function as a means of storing value (currency). The next change, people began to recognize money which is still used today, namely the types of currency and demand deposits, in line with technological developments, people use digital technology to create a digital exchange system or what is now known as electronic money (e-money). (Firmansyah \& Dacholfany, 2018).

With the increasing use of the benefits of digital technology as a transaction tool, some people think that the fiat money system as a medium of exchange in transactions currently being used is still limited by a country's regulatory rules and privacy limitations, the imposition of transaction fees, being affected by inflation and other limitations. People perceive limitations as anxiety which eventually emerges an idea, namely creating a new currency in the hope of overcoming the 
limitations of the fiat money system, so that people can transact without third party interference over their privacy, until finally cryptographic-based currencies emerge (Wijaya, 2018).

Cryptography is a branch of mixed science based on mathematical calculations, computer and mathematicians discover the potential of cryptography and utilize it for social economic activities, especially in buying and selling transactions and as a cryptocurrency-based digital currency. Cryptocurrency is digital money that is designed using the security of cryptographic technology, this makes crypto money difficult to forge and has absolute privacy advantages, its use scheme does not require an intermediary as a third party from the institution or institution, so the owner can manage and manage it independently, and transactions that can be executed instantly and across countries. (Mulyanto, 2015). There are many types of cryptocurrencies, including Bitcoin, Ethereum, XRP, Tether, Binance Coin, Cardano, and others, the most common type of cryptocurrency known by the public globally is Bitcoin.

Another main advantage that is owned by Bitcoin is the Blockchain system. In addition, this cryptocurrency has weaknesses, including not being based on assets (underlaying assets), the absence of a control system from the institution that is responsible as an authority, and being prone to being used as a means of crime. such as money laundering because it is not accompanied by the clear name of the owner. Legally, cryptocurrency itself is widely opposed by institutions that have authority in several countries, such as in Iceland, the Icelandic Central Bank stated that the use of crypto currency is still considered illegal. The Russian state through the Central Bank warns people who use Bitcoin as a means of payment transactions with the potential for crimes such as acts of terrorism and money laundering.

In Indonesia itself, cryptocurrencies do not yet have legality issued by the government, so that it becomes a dynamic of pros and cons (Azizah, 2020). The dynamics of pros and cons also occur in views among economists and scholars in using cryptocurrency as a means of business transactions, this is because cryptocurrency has not met the criteria and several elements as currency, especially on Islamic economic principles. The purpose of this article is an attempt to find out how the description of cryptocurrency technology as digital money, as well as to describe the law on the use of cryptocurrencies as currency with a ushul fiqh approach.

Similar research that discusses the legal position of using cryptocurrency in an Islamic perspective has been carried out. (1) Husnul Fatarib and Meirison's research entitled "Cryptocurrency and Digital Money in Islam Is It Legal" was published in Jurisdiction: Journal of Law and Sharia, Volume 11 No. 2 of 2020. The focus of this research is on the characteristics and elements of money in Islamic law associated with the role of gold as an intrinsic value issued by the government. Where the results of his research show that the currency recognized in Islamic economics is the currency issued by state authorities. Bitcoin and other cryptocurrencies are not included as currencies in Islamic law, due to high uncertainty and the potential for harming individuals and countries (Fatarib \& Meirison, 2020). (2) Luqman Nurhisam's research published in the ArRaniry International Journal, Volume 4 No. 1 Year 2017, with the article title "Bitcoin in the Eyes of Islamic Law". This article discusses the increasing use of Bitcoin by the public. The results of this study state that the use of Bitcoin is forbidden in the eyes of Islamic law, because there are more harms than benefits. The novelty and difference of this research with previous research, namely from the aspect of the object of research, the discussion on the object of research emphasizes more on cryptocurrency or Bitcoin technology and its views from the side of Islamic sharia. Another rock value is in legal istinbath using ushul fiqh instruments, starting from the Koran, hadith, qiyas, and maslahah al-muarsalah, and also seen from the maqashid aspect of sharia (Nurhisam, 2017). 


\section{RESEARCH METHODS}

This research is a type of qualitative research. Qualitative research can be understood as a research procedure that utilizes descriptive data. The purpose of this qualitative research is to describe and analyze events, social dynamics, phenomena and attitudes of individual and group perceptions of something. This research approach uses a normative syar'i approach, namely conducting research by studying Islamic sharia studies. The purpose of this approach is to find out the conclusions from the aspects studied referring to Islamic law. The syar'i normative approach in this study is to use the ushul fiqh approach as an istinbath method in determining cryptocurrency law as a transaction tool.

\section{RESULTS AND DISCUSSION}

\subsection{CRYPTOCURRENCY TECHNOLOGY}

Crypto currency is a digital or virtual type of currency, where transactions are carried out only through a network (internet). Different from fiat currencies that are printed such as paper and coins, cryptocurrencies are designed based on cryptography by solving mathematical problems (Tejosusilo, 2019). Cryptography technology helps cryptocurrencies cannot be easily duplicated or transferred to other parties who cannot access and are not the owner. Cryptocurrency can be said to be a digital asset designed to be used as a cryptographic-based exchange medium through encryption algorithms for securing financial transactions, controlling new additional units, as well as validating and verifying asset transfer activities.

\subsection{BLOCKCHAIN SYSTEM}

Basically, blockchain is a decentralized based virtual data system. The digital transaction recording scheme consists of many servers, in the sense that data is not stored in one place, but is spread across all nodes, therefore it is normatively a resistance to data modification. Blockchain is an openly distributed ledger, and the efficient and permanent record of transactions is verified. The blockchain system is a trust engine in transactions, which is useful when institutions and intermediaries have problems, or can overcome trust gaps between transacting organizations (Cukier, 2018). Nakamoto explains the working pattern of the blockchain contained in Bitcoin as follows.

\subsection{TRANSACTION SYSTEM}

This cryptocurrency transaction mechanism system can be said to be very interesting, where this crypto currency can be done with quite high flexibility, transactions can be carried out at any time, anytime, anywhere and anywhere in the world. The tool needed in the transaction is a PC or smartphone that has network (internet) access. The use of cryptocurrencies or cryptocurrencies, the basic concept is the recording of the entire history of ongoing transactions, including the transaction value and purpose. When someone sends money to the recipient, every information will be given to both parties, this is equipped with a private key for security in the form of a digital signature (Hamin, 2020). Cryptocurrencies are usually governed by a set protocol that determines how many coins can be created, how they are created and how the integrity of the ledger is protected. This protocol is intended to be on par with government regulations and laws that support fiat money, and its strength will affect trust in digital currencies, and therefore, their supply and demand, usually cryptocurrency blockchains are regulated in such a way that it is difficult or impossible to change the protocol. operation (Siswantoro et al., 2020).

\subsection{MINING}

The term mining is often heard in the cryptocurrency world. This mining activity is an activity in the search for crypto currency. Unlike banking, all transactions in circulation will be recorded directly, cryptocurrencies do not go through third parties as intermediaries who can verify and record 
all transactions. This is where mining activities are carried out, namely efforts to find new blocks by solving mathematical algorithm formulas. The miner who successfully validates the transaction activity for the first time will get a new amount of cryptocurrency as a reward that has been prepared for the miner. The prizes that have been prepared, are not from existing crypto money. For example, the Bitcoin algorithm of money has been designed to only amount to 21 million Bitcoins.

\subsection{USE OF CRYPTOCURRENCY}

The use of cryptocurrencies is not only used as a means or means of payment, but is also in fact used for investing and trading cryptocurrencies. The first recorded use of cryptocurrencies as a transaction tool was the purchase of two Papa John pizzas by Laszlo Hanyecz, he exchanged 10 thousand Bitcoins for Bitcoin by buying two large Papa John pizza pans. After that until now many sites or entrepreneurs that allow payments such as amazon, namecheap, wordpress and several wellknown brands use crypto currency as a transaction tool. However, the legal status of cryptocurrency itself still varies and is still changing in various countries, there are some countries that clearly allow it and there are some countries that explicitly prohibit or restrict the use of this cryptocurrency. In the 2018 Library if Congress, there were at least eight countries that absolutely prohibited the use of cryptocurrencies, including Algeria, Egypt, Morocco, Bolivia, Nepal, United Arab Emirates and Pakistan. While implicitly in various other countries, such as Bangladesh, Bahrain, Colombia, Iran and including Indonesia (The Law Library if Congress, 2018). In Indonesia, the use of crypto currency as a domestic payment instrument is considered illegal. Law No. 7 of 2011 concerning Currency in Article 1 Paragraph 1 it is explained that the payment instrument accepted and considered valid in Indonesia is only Rupiah.

\subsection{CRYPTOCURRENCY IN ISLAMIC LAW}

In determining or establishing cryptocurrency laws, Islam has its own methods and sources of reference, both from primary sources, namely the Koran and al-Hadith, both sources are analyzed as references in establishing law by mujtahids, besides that mujtahids also recognize other methods in establish laws, such as qiyas, maslahah mursalah ad-zariah and others. The method in determining the syar'i law is known as the science of ushul fiqh. (a). Al-Quran Verses of the Koran that represent economic activities or activities in general, including cryptocurrencies can be found in the Quran in Surah an-Nisa verse 29:

O you who believe! Do not eat each other's property with vanity (not right), except in trade which is carried out on the basis of consensual between you. And don't kill yourself. Indeed, Allah is Most Merciful to you. (Surah An-Nisa 4:29) The verse above explains that every transaction activity must be avoided from vanity. The word batil itself has a broad meaning in understanding it, such as every transaction carried out must be in accordance with the values of Islamic teachings, or not violate Islamic teachings. The word batil itself has the meaning of facade which means damaged, useless, useless and false, which comes from the origin of the word bathala-yabthulu-bathlan. In terminology, batil is defined as the antonym of something that is haqq (truth), namely something that has no good benefits (in vain) either in this world or in the hereafter (Al-Asfahani, 2012). In Tafsir al-Munir, the batil method is a method that is forbidden in Islamic law, such as ribawi transactions, maysir (gambling elements), gharar and so on. The consequence of batil itself is that the contract is damaged and void (Zuhaili, 1998). In relation to the use of cryptocurrencies, currently crypto currency users are using it more for speculating and trading tools. It aims to profit from investing and trading activities with speculation. This in Islam contains elements of gharar, maysir and usury. In the Quran, Surah al-Maidah verse 50 is explained such as ribawi transactions, maysir (gambling elements), gharar and so on. In the Quran, Surah al-Maidah verse 50 is explained : 
O you who believe! Indeed, drinking, gambling, (sacrificing for) idols, and drawing lots of luck with arrows, are heinous acts and are included in the actions of the devil. So stay away from those (actions) so that you will be successful (Surah Al-Maidah 5:50). Cryptocurrencies today still contain high price volatility, and volatility to very high value fluctuations, this is synonymous with speculation on price differences. So that the intention to get results or profits from the price difference is included in the elements of gharar and maysir if used for investing and trading crypto currency. (b). Hadith The concept of cryptocurrencies as a means of buying and selling transactions can be seen in the hadith of Ubadah bin Shamit, "If gold is sold for gold, silver is sold for silver, wheat is sold for wheat, sya'ir (a type of wheat) is sold with sya'ir, dates are sold with dates, and salt is sold with salt, then the amount (measures or scales) must be the same and paid in cash (cash). If the types of goods are different, then feel free to barter them as you like, but it must be done in cash (cash)." (HR. Muslim no. 1587). In the hadith there are two keywords in conducting transactions, namely the exchange must be of the same value or measure and the transaction must be done in cash. Cryptocurrencies are analogous to the exchange of gold for gold and silver for silver. Cryptocurrency exchange can be exchanged for other currencies such as dollars and rupiah, in fiqh this currency exchange is called sharf. Imam Ibn Taymiyah in Majmu' Fatawa explains that money is an object that has been agreed upon by users to be used as a medium of exchange, even if it is from a stone or a piece of wood. This means that the use of cryptocurrencies up to this point is allowed, but Imam Al-Gazali requires the use of currency to be issued and circulated by government authorities and the government has declared the money to be a legal and official means of payment transactions (Mansur, 2009).

Cryptocurrency is still a debate in its use in various countries, Indonesia itself has not or even banned the use of cryptocurrency as a legal means of payment transactions. So in this case, the use of cryptocurrencies as a currency and a means of payment transactions is not allowed from a sharia point of view, because Islam itself emphasizes obeying orders or rules from ulil amri, in this case the government. But then, this crypto currency does not yet have clarity and cannot be seen in its physical form, and there is no legal certainty in legality either in Indonesia itself or in global agreements, therefore it can still be called gray and gharar, especially its use in investment and trading, which makes this crypto currency inseparable from price speculation which is very volatile and its use is only as a means of profit and loss, so it contains an element of maysir. Islamic law prohibits transactions that contain elements of gharar and maysir hadith of the Prophet SAW. narrated by Abu Hurairah: "The Messenger of Allah, sallallaahu 'alaihi wa sallam, forbade the buying and selling of al-hashah and buying and selling of gharar" (HR. Muslim: 1513) c. Qiyas Qiyas is one of the methods of ijtihad in establishing laws related to Islamic law. Qias has the meaning of taqdiru assyay'i bi ghairihi which means measuring an object with something that is universal and has characteristics that match the object (Hasan, 2001).

The pillars in determining the law with the qiyas method must meet four elements, the first is ashl (basic) which is something contained in the texts and becomes a measure in determining the law. The second is that far'un (branch) is something that is not stated in the texts and the legal stipulation is adjusted to asl, the third is hukmul al-ashl (basic law), namely the basic law written in the texts which will be referred to by law for far'un, and fourth is illat (legal motive) which is a certain condition that is used as the basis for taking asl law (Mufid, 2018). In determining cryptocurrency law, it can be confirmed with the hadith of Imam Malik. "Yahya told me, from Malik, from Nafi', from Abdullah ibn Umar that the Messenger of Allah -peace and prayer of Allah be upon himforbade the buying and selling of hablu al-hablah. This buying and selling is a practice of buying and selling in the Jahiliyah community, where someone sells a camel that will be born by a fetus, but the 
fetus is still in the mother's belly" (al-Muwatha, 1359). The above hadith explains the prohibition of buying and selling hablu al-habla, is selling camel fetuses that are still in the womb of their mother. The prohibition of buying and selling is due to jahalah (unknown) nature and character. The jahalah element results in the emergence of gharar and mysir elements which result in speculation (chance). Cryptocurrency transactions can be analogous to hablu al-habla transactions with asl buying and selling hablu al-habla. The far'un is buying and selling cryptocurrencies. His hukmul al-shl is haraam buying and selling hablu al-habla. Illat or the legal motive is to have in common the transactions that are not clear (jahalah), either in terms of quantity or quality. d. Sadd-adzariah The word sad has the meaning of closing something that is damaged, defective, or perforated", while adzariah means "blocking the way to a destination". Imam al-Syaitibi defines adzariah as doing something that initially contains benefits but aims at harm. Ibn Qayyim al-Jauziyah added that adzariah is not limited to something that is prohibited (sadd adzariah), but can also be something that is recommended (fath adzariah) (Al-Jawzi, 1996). From this explanation, it can be concluded that sadd adzariah is an act carried out by someone that contains benefits, but leads to harm or damage. Imam al-Syaitibi is of the view that there are at least three benchmarks in sadd adzariah in seeing the act as forbidden.

First, the act that was originally allowed to be done contains mafsadat. Second, the level of harm is greater than benefit. third, the actions that are allowed contain more elements of mafsadat (AsySyaitibi, nd). Cryptocurrencies from the beginning of their emergence until now, are still a concern among people in various worlds, the pros and cons regarding the legality of their use, both from positive law to the view of Islamic sharia is a separate phenomenon. The volatility of the price and the uncertainty of this currency is what makes the debate. Basically, Islamic sharia views that everything is permissible in the aspect of muamalah, until there are arguments that prohibit it. The users of cryptocurrencies around the world are countless, this shows that this currency has been recognized by the public, especially by its users, it can be said that the use of crypto currency for transactions is permitted under urf, but behind the advantages of this crypto currency, it cannot be viewed from the ontological point of view of its existence in urf only, However, it must be considered comprehensively from many aspects. As has been explained that the value of the crypto currency itself changes very quickly and fluctuates high, so that it has an impact on concerns about the occurrence of a bubble economy due to speculation from its users, besides that crypto currency contains elements of jahalah (unclearness) and is used as trading that includes elements of maysir and fall on the practice of usury, where traders buy when prices are low in the hope of selling when prices go high. It can be said that this cryptocurrency is only used as a speculation tool, not purely an investment. Some of the dangerous aspects of using cryptocurrencies, among others, are vulnerable to the risk of economic bubbles, which have a detrimental impact on the wider community. In addition, cryptocurrencies are not issued by central government authorities, and there is no supervision or monitoring from the central government, so that it can cause great harm, both for money laundering, terrorist crimes and so on. Thus, when viewed from the adzariah method, the use of this cryptocurrency contains something that will have a greater impact on harm (sad adzariah). It can be said that this cryptocurrency is only used as a speculation tool, not purely an investment. Some of the dangerous aspects of using cryptocurrencies, among others, are vulnerable to the risk of economic bubbles, which have a detrimental impact on the wider community. In addition, cryptocurrencies are not issued by central government authorities, and there is no supervision or monitoring from the central government, so that it can cause great harm, both for money laundering, terrorist crimes and so on. Thus, when viewed from the adzariah method, the use of this cryptocurrency contains something that will have a greater impact on harm (sad adzariah). It can be said that this cryptocurrency is only used as a speculation tool, not purely an investment. Some of 
the dangerous aspects of using cryptocurrencies, among others, are vulnerable to the risk of economic bubbles, which have a detrimental impact on the wider community. In addition, cryptocurrencies are not issued by central government authorities, and there is no supervision or monitoring from the central government, so that it can cause great harm, both for money laundering, terrorist crimes and so on. Thus, when viewed from the adzariah method, the use of this cryptocurrency contains something that will have a greater impact on harm (sad adzariah). Some of the dangerous aspects of using cryptocurrencies, among others, are vulnerable to the risk of economic bubbles, which have a detrimental impact on the wider community. In addition, cryptocurrencies are not issued by central government authorities, and there is no supervision or monitoring from the central government, so that it can cause great harm, both for money laundering, terrorist crimes and so on. Thus, when viewed from the adzariah method, the use of this cryptocurrency contains something that will have a greater impact on harm (sad adzariah). Some of the dangerous aspects of using cryptocurrencies, among others, are vulnerable to the risk of economic bubbles, which have a detrimental impact on the wider community. In addition, cryptocurrencies are not issued by central government authorities, and there is no supervision or monitoring from the central government, so that it can cause great harm, both for money laundering, terrorist crimes and so on. Thus, when viewed from the adzariah method, the use of this cryptocurrency contains something that will have a greater impact on harm (sad adzariah). and there is no supervision or monitoring from the central government, so that it can cause great harm, both for money laundering, terrorist crimes and so on. Thus, when viewed from the adzariah method, the use of this cryptocurrency contains something that will have a greater impact on harm (sad adzariah). and there is no supervision or monitoring from the central government, so that it can cause great harm, both for money laundering, terrorist crimes and so on. Thus, when viewed from the adzariah method, the use of this cryptocurrency contains something that will have a greater impact on harm (sad adzariah). In the rules of fiqh it is explained that "Rejecting evil takes precedence over realizing benefit".

\section{CONCLUSION}

The existence of cryptocurrency as an innovation and technological development that uses the blockchain system has many positive impacts such as convenience and speed in conducting transactions, it is cheaper and more confidential and can be used across countries and across continents. Islamic religious teachings in discussing aspects of muamalah recognize the rules fiqh "Basically every muamalah activity is permissible until there is evidence that forbids it". Basically the existence of cryptocurrency as a virtual currency is allowed, because it has been recognized by various people, however, legality and recognition by the government must be seen as rights and obligations of the government. Included in the issuance of the currency, this is to avoid the possibility of fraud that can occur. In practice, currently cryptocurrency transactions are more widely used as speculation which results in elements of gharar and maysir which are included in the form of vanity or elements that are prohibited by the principles of Islamic teachings. Cryptocurrency transactions are based on buying and selling (hablu al habla) buying and selling of camel fetuses in the womb. The use of cryptocurrency as an investment instrument contains high speculation that is chancy. The use of crypto currency can also be seen with the sad adzariah method, with ambiguity and containing elements of gharar and maysir, especially the unclear legality of the government regarding the use of this cryptocurrency, it will have a greater negative impact such as misappropriation and use of funds for crimes such as terrorism and money laundering. Therefore, the prevention of harm or harm is prioritized over its usefulness. 


\section{REFERENCE}

Al-Asfahani. (2012). Al-Mufradat fi Gharib Al-Quran. Dar ibn Jauzy.

Al-Ghazali. (1993). al-Mustasfa fi Ilmi al-Usul. Dar al-Kutub al-'ilmiah.

Al-Jawzi, I. al-Q. (1996). A'lam al-Muwaqi'in (Juz II). Dar al-Kutub al-'ilmiah.

Ash-Syaitibi, II (nd). Al-Muwafaqat fi ushul al-Syariah (Juz II). Dar al-Marifah.

Azizah, ASN (2020). Cryptocurrency Phenomenon in the Perspective of Islamic Law. Shaoutuna: Scientific Journal of Comparative Madzhab Students, 1(1), 62-80.

Cukier, K. (2018). The meaning of the blockchain. The Economist.

Fatarib, H., \& Meirison. (2020). Cryptocurrency And Digital Money In Islam: Is It Legal? Jurisdiction: Journal of Law and Sharia, 11(2).

Firmansyah, \& Dacholfany, MI (2018). Electronic Money in the Perspective of Islamic Economics. IQRA CV.

Hamin, DI (2020). Crypto Currence and the View of Legality According to Islam: A Literature Review. Scientific Journal of Management and Business, 3(2), 127-139.

Hasan, A. (2001). Analogical Reasoning in Islamic Jurisprudence, Indonesian Edition, Qiyas Analytical Reasoning in Islamic Law (1st ed.). References.

Ilham, R. N., Erlina, K. A. F., Silalahi, A. S., Saputra, J., \& Albra, W. (2019). Investigation of the bitcoin effects on the country revenues via virtual tax transactions for purchasing management. Int. J Sup. Chain. Mgt Vol, 8(6), 737.

Mansur, A. (2009). The Concept of Money in the Perspective of Islamic Economics and Conventional Economics. Al-Qanun, 12(1), 78.

Mufid, M. (2018). Ushul Fiqh of Contemporary Economics and Finance from Theory to Application (Second). Prenada Media.

Mulyanto, F. (2015). Utilization of Cryptocurrency as the Application of Rupiah Currency into Digital Form Using Bitcoin Technology. Indonesian Journal on Networking and Security, 4(4).

Nurhisam, L. (2017). Bitcoin in the Eyes of Islamic Law. Ar-Raniry International Journal, 4(1), 165186.

Nur Ilham, R. ., Arliansyah, A., Juanda, R., Multazam, M. ., \& Saifanur, A. . (2021). RELATHIONSIP BETWEEN MONEY VELOCITY AND INFLATION TO INCREASING STOCK INVESTMENT RETURN: EFFECTIVE STRATEGIC BY JAKARTA AUTOMATED TRADING SYSTEM NEXT GENERATION (JATS-NG) PLATFORM. International Journal of Economic, Business, Accounting, Agriculture Management and Sharia Administration (IJEBAS), 1(1), 87-92. https://doi.org/10.54443/ijebas.v1i1.27

Riinawati, R. (2021). Education Financial Management during Covid-19 Pandemic of Islamic Universities in South Kalimantan. Dinamika Ilmu: Jurnal Pendidikan, 383-396.

Satoshi, N. (2016). a peer-to-peer electronic cash system. Retrieved from Www.Bitcoin.Org: Satoshi Nakamoto Satoshin@ Gmx.Com.Www.Bitcoin.Org.

Saujana, P. (2020). Bitcoin Mined Out? This Will Happen Soon. Blockchainmedia.Id.https://blockchainmedia.id/bitcoin-habisdiambang-ini-later-yanghappen/

Siswantoro, D., Handika, R., \& Mita, AF (2020). The requirements of cryptocurrency for money, an Islamic view. Heliyon.https://doi.org/https://doi.org/10.1016/j.heliyon. 2020.e03235

Tejosusilo, EO (2019). What is Cryptocurrency (Digital Currency)? My finances.

The Law Library if Congress. (2018). Regulation of Cryptocurrencies Around the World. The Law Library of Congress. 


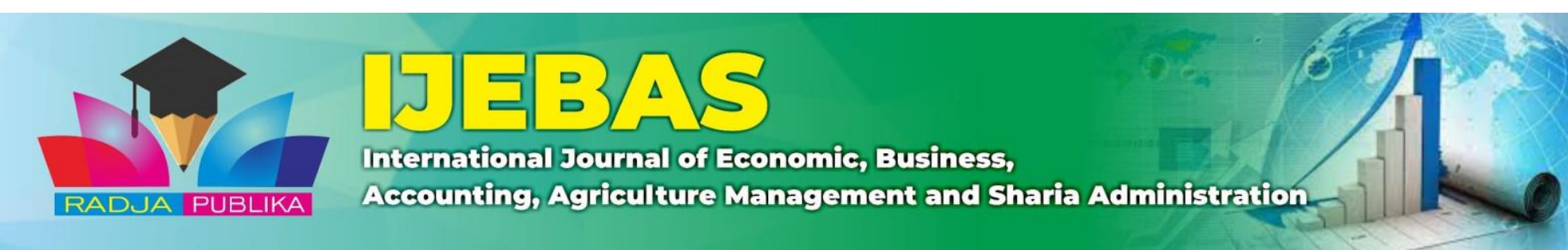

Wijaya, DA (2018). Bitcoin Mining and Other Cryptocurrencies. jassacom.

Zuhaili, W. (1998). Tafsir al-Munir fi al-Aqidah wa al-Sharia wa al-Manhaj. Dar al-Fikri. 